\title{
Situating the Figure of Papas, Pagarch of Edfu at the End of the Seventh Century: The Contribution of the Coptic Documents
}

In 1953, the French papyrologist Roger Rémondon published a hundred Greek documents from excavations in the vicinity of the Pharaonic temple of Edfu carried out in 1921-1922 by the archaeologist Henri Henne. ${ }^{1}$ These documents, known as P.Apoll., constitute the archive of Papas, pagarch of Apollonopolis (Magna), the modern Edfu. Papas was the administrator of the city and the surrounding district in the last part of the seventh century. These papyri had been preserved in a jar, but during the transport of the jar from Edfu to the IFAO in Cairo, all of them disintegrated into fragments. ${ }^{2}$ Under these conditions, the work of reconstruction and interpretation of the Greek texts carried out by Rémondon deserves our admiration. However, the jar also contained Coptic papyri, on which Rémondon, without publishing any of them, passed the following judgment:

As I have said above, there were also Coptic papyri in this jar. They are less numerous than the Greek, and equally badly preserved. Reading them as thoroughly and attentively as possible has shown that they are usually private letters, often written by priests or monks. Whether they are Greek or Coptic, all the documents concern the same person, named Papas, so the jar did not contain the archive of a family, but of one single individual. ${ }^{3}$

This archive was assigned to the beginning of the eighth century by Rémondon, but that date was later revised by Jean Gascou and Klaas Worp, ${ }^{4}$ who assigned the papyri convincingly to the 670s, making the archive a very important body of material for the study of the administration of Egypt at that time. Some years later, Leslie MacCoull began to reconsider a number of the Coptic papyri, questioning the idea that

1 Rémondon (1953).

2 See Rémondon (1953) V. On the jar and the way in which the papyri were kept inside, see Marchand (2013). In addition, some pieces were apparently diverted at the very moment of their discovery and sold on the antiquities market; these are PSI XII 1266 (= P.Apoll. 9), 1267 (= P.Apoll. 24), XIII 1345, and XV 1570, kept at the Istituto papirologico “G.Vitelli” in Florence, P.Princ. III 140 (= SB XX 14282), P.Merton I 49, P.Mil. inv. 70.19 (= SB XXIV 16316) and inv. 89 (= SB XXIV 16317), as well as SB Kopt. I 242 (on which see below $\S 2.1)$.

3 Rémondon (1953) VI (Introduction): “Comme je l'ai dit plus haut, il y avait aussi dans cette jarre des papyrus coptes: ils sont moins nombreux que les grecs et tout aussi mal conservés. Une lecture aussi complète et attentive que possible m'a permis de constater qu'il s'agit généralement de lettres privées, souvent écrites par des prêtres ou des moines. Qu'ils soient grecs ou qu'ils soient coptes, tous les documents concernent le même personnage, nommé Papas, en sorte que la jarre ne renfermait pas les archives d'une famille, mais d'un seul individu.”

4 Gascou/Worp (1982). 
Coptic documents would necessarily be private and showing that they concern the same "official" subjects as the Greek documents. ${ }^{5}$ The data provided both by the publication of P.Apoll. and by MacCoull's study has been used in an enlightening article by Clive Foss that gives a general picture of Papas' responsibilities, activities and relationships with various administrative levels. ${ }^{6}$ Since MacCoull's article, the Coptic papyri have remained unpublished. In the early 2000s, Geneviève Favrelle, an independent French researcher, proceeded to reconstruct and transcribe many texts, but the magnitude of the task did not allow her to publish anything before her death. In 2015, Alain Delattre, who is now in charge of the IFAO dossier, agreed to launch a collective project on the Coptic papyri in this archive. A team of about ten people is now working more or less systematically on these texts. ${ }^{7}$ We have been able to carry out two week-long studies at the IFAO (January 2016 and April 2017). A first batch of documents has been published in the BIFAO. ${ }^{8}$

Considering once again Rémondon's remarks on the Coptic papyri in light of our preliminary work, we can already qualify them: (1) the Coptic papyri were not less numerous than the Greek ones, as the fragments probably come from more than 150 documents; (2) although there are some Coptic letters written by priests and monks, the majority of the Coptic documents cannot simply be characterized as "private," and the concept of "privacy" requires further interrogation; (3) the claim that all the documents refer to Papas may be contradicted by some of the Coptic documents, although this point has yet to be securely established. ${ }^{9}$ The aim of this paper is thus to take this discussion forward by a step or two and to present some of the progress we have made on understanding the figure of Papas, especially through consideration of the respective statuses of the Greek and Coptic papyri from the jar.

\footnotetext{
5 MacCoull (1988).

6 Foss (2009).

7 The team includes, in addition to Alain Delattre and myself, Lajos Berkes, Ruey-Lin Chang, JeanLuc Fournet, Esther Garel, Jean Gascou, Isabelle Marthot-Santaniello, Grzegorz Ochała, and Naïm Vanthieghem. I would like to thank Alain Delattre and Lajos Berkes for reading and commenting on a draft of this article, as well as Korshi Dosoo, who in addition has taken the trouble of revising the English.

8 Boud'hors/Delattre (2017). The team is also revisiting a number of the Greek papyri from the archive.

9 If $S B$ Kopt. I 242 was once part of the material kept in the jar (see above n. 2 and below $\S 2.1$ ), this provides a clue that the archive does not concern only Papas, but also his father Liberios. P. Apoll. 74 could also belong to an earlier period (see below § 1.1.), as could a Greek fragment that Ruey-Lin Chang published in the BIFAO collective article mentioned above if the fragment in question is indeed from the jar, as it has been thought to be up to now.
} 


\section{Private documents}

\subsection{The Coptic side of P.Apoll. 74}

P.Apoll. may fairly be reproached for failing in every case to mention the presence of Coptic texts on the back of Greek documents. There are several cases of reused papyri, as evidenced by the work carried out over the last two years. Among them, P.Apoll. 74 is especially noteworthy, as it may provide the basis of Rémondon's impression of the nature of the Coptic texts. One of the longest Coptic texts is preserved on the back of this "list of onomata."10 It consists of a rough draft of an arbitration report and is very interesting in many respects. The object of the dispute is the inheritance of a half-cell or half-chamber. A large number of people are called to testify, including Abdias, priest of (the church of?) Perpé, and another priest from the same place (maybe also named Papas), as well as Iohannes, deacon of the holy topos of Epiphanios, and Tsina, daughter of the priest Souai, who are called to declare under oath what they know before the bishop. A certain Markos, described as eulabestatos, and therefore probably also an ecclesiastical figure, is one of the parties, as the deceased owner owed him some money.

This text makes no direct mention of the pagarch Papas and may have been written before Papas took office and perhaps even before the conquest. It cannot have escaped Rémondon's attention, and it probably contributed to his perception of the Coptic papyri as having been written mainly by clerics and monks. This Coptic draft was obviously reused to write the Greek account. This document thus makes it possible to understand why Rémondon seems to have perceived the Coptic material as "private": this text is indeed private, but it is part of Papas' archives only by accident, because Papas or a member of his staff reused it to copy the Greek account.

\subsection{An example of a letter issuing from a monastic milieu}

Another text that Rémondon might have had in mind is P.IFAO Edfou Jarre inv. $19 .{ }^{11}$ It is the lower part of a letter, clearly addressed by monks to a civil authority. Since the title megaloprepestatos ("most magnificent") is given to this authority, the addressee was most likely the pagarch. The leaders of a monastery ask for help, using rhetoric that refers to the well-known Byzantine patterns of relationships between great landowners and the monasteries of which they were the benefactors. ${ }^{12}$ As such a landowner, Papas is likely to have played this role:13

10 The Coptic text has been published by A. Boud'hors and A. Delattre while E. Garel and J. Gascou reedited the Greek portion: Boud'hors/Delattre (2018) 2-24.

11 Marthot-Santaniello in: Boud'hors/Delattre (2017) 107-109.

12 See for instance Rémondon (1972) and Papaconstantinou (2012). 
So be kind enough to make an effort to [...] agree with them about the two acacias, so that God will bring you our prayers and our blessings in abundance, in exchange for the deeds you do for the holy monastery. The main thing is that I greet your filial Greatness [...] I pray to the measure of my humility that the Lord God will bring our prayers [...] to you and all of yours and grant you a reward for the deeds you do for the holy monastery, in this place and in the next (= in this world and in the world to come). [Greeting in the] Holy Trinity!

Apart from these two texts, which can be regarded as private and show Papas' relationships with the religious institutions belonging to his pagarchy, and a few others which likewise testify to his role as a benefactor, very few texts concern priests and monks. Before going any further into other texts, I would like to offer some reflections and questions on the meaning of "privacy" in an archive of this kind.

\section{Privacy: modes and manifestations}

\subsection{What is private in Papas' archive?}

Obviously, the opposition that concerns us here is not between family life and professional life, as the entire correspondence of Papas concerns his professional life. We learn very little about the members of his family from the Greek or the Coptic documents. We should note also that the use of the term "brother" in several types of relationships tends to confuse matters.

None of the Coptic documents kept at the IFAO, to the best of my knowledge, mentions Papas' father, Liberios, who was pagarch of Edfu before his son, nor Papas' wife Sara, nor his children. The only Coptic document concerned with Liberios as a pagarch, namely SB Kopt. I 242, does not mention Papas. It is a declaration (homologia) addressed to Liberios, pagarch of Edfu, by various corporations, attesting the receipt of quantities of pepper that were to be redistributed by each corporation head within his corporation and paid for. ${ }^{14}$ As for his brother Iohannes, who is called kyros Iohannes in the Greek texts, further investigation is still needed, as there are several occurrences of a kyros Iohannes in the Coptic documents, but both the name and the title are very common and could refer to several different people.

As in many other archives or groups of documents, the texts fall into two large groups, one group dealing with the management of public affairs, which basically consisted of receiving the various orders of taxation and requisitions and apportioning them to citizens, and another dealing with the management of Papas' affairs as a landowner and local notable. The texts in the latter category include lease or loan contracts, income or expenditure accounts (which are frequent among the Greek

13 Foss (2009) 7 observes that "the majority of the expenses in this account [P.Apoll. 98] went to the church."

14 Edited in Crum (1925). On the significance of this document in the interpretation of the content of the jar, see above n. 9. 
texts, but virtually non-existent in the Coptic texts), arbitration of local conflicts, ${ }^{15}$ and relationships with religious institutions.

However, the dividing line between the two categories is not always clear. ${ }^{16}$ The fiscal pressure of the Arab administration had repercussions for the daily lives of Papas' citizens and people. As a pagarch, Papas was responsible, on the one hand, for the organization of the payment of taxes, requisitions, etc., and on the other hand responsible for maintaining a degree of equity in the population and supporting the weakest members of society. The Coptic documents provide a particularly good perspective on this uncomfortable position as an intermediary.

\subsection{The status of deacons and their role in public affairs}

In Papas' archive, as again in many other documents, especially after the Arab conquest, deacons are often mentioned as intermediaries in public affairs not specifically linked to the Church. ${ }^{17}$ Therefore, this title should not lead us to any hasty conclusions about the nature of a text.

\subsection{The importance of paleography}

The two ostensibly private documents mentioned above (P.Apoll 74 recto and P.IFAO Edfou Jarre inv. 19) are written in a bilinear majuscule typical of private Coptic documents. On the other hand, a large number of other Coptic documents are written in professional cursives close to those of the Greek documents. Moreover, their addresses are often in Greek. Obviously, these documents, whatever their language, were issued by the same circles and offices.

We shall now examine some examples of the various categories of administrative documents the Coptic documents can be assigned to.

15 See for instance P.Apoll. 61, a Greek letter from Liberios to Papas to exhort him to reconcile a mother and her son, and the Coptic arbitration P.Apoll. 74 recto described above in 1. 1.

16 This phenomenon is well known for Egypt in Late Antiquity and had been dealt with by several authors; see for instance Tost (2012).

17 See P.Apoll. 10, 37, and several Coptic papyri (Jarre inv. 21 [deacon Severos] and 25 [deacon Severos, perhaps the same individual]). This increasing presence of deacons in Coptic documents outside the ecclesiastical sphere has been recently emphasized by Garel (2017). 


\section{Different types of Coptic documents related with "official" affairs}

\subsection{Orders from "above"}

Even at the highest level, that is to say in the orders transmitted by officials in the Arab administration, Coptic seems to be used at times. A convincing example is provided by P.IFAO Edfou Jarre inv. 205, ${ }^{18}$ a letter concerning the requisition of equipment for the fleet, in which the final greeting, †рнмн мак ("peace be upon you"), suggests that this document comes from an official in the Arab administration. This is probably not the only example of such a document, as this final salutation has been identified in two or three other Coptic fragments. This letter refers to an amir (Coptic амира or амєра), as do several other Coptic and Greek documents. Rémondon suggested that the word amir refers to the duke of Thebaid. However, according to a recent article by Federico Morelli, this title corresponds to a title of "commander", whose origins were military, but whose function and place in the hierarchy remain rather vague. ${ }^{19}$

\subsection{Between people of the same rank}

A large number of the Coptic documents preserve greeting formulas or addresses in which Papas is designated by his most common titles, peribleptos, theophylaktos, or megaloprepestatos. The addresses are similar to those of Greek documents ("To give to the illustrious brother, the kyrios protected by God (...) from ...”). These letters seem to come either from the secretaries (notarioi) of the ducal office, or from colleagues (other pagarchs?). As emphasized by Clive Foss, such secretaries (notarioi) are omnipresent in the archive. ${ }^{20}$ They belong to the same class as Papas. They therefore transmit orders, but address Papas with stereotypical formulas showing that they are equals or colleagues. The Greek letters of the archive have preserved the names of several of them: Helladios, Theodoros, Elias, Kollouthos. As for the Coptic papyri, no name has been securely identified at this point. However, two examples show the possible variations and nuances in these relationships.

The first one is a letter, where the formulas and tone recall some Greek letters written to Papas by Elias, notary of the topotereetees (who is the assistant of the dux): ${ }^{21}$

18 The text was first analyzed by MacCoull (1988) 142. It has been reconstructed and studied by Lajos Berkes, in Boud'hors/Delattre (2017) 90-93.

19 Morelli (2016).

20 Foss (2009) 8.

21 P.IFAO Edfou Jarre inv. 21+34, see Garel in Boud'hors/Delattre (2017) 93-98. 
Here are the two lists I have sent to your brotherly Illustriousness, those for which the deacon Seuēros has vouched ...

The second example is another letter addressed to Papas: ${ }^{22}$

† Before all (things) I greet your (pl.) illustrious (peribleptos) lord and brother. For indeed, it has been a long time since we were not worthy of (receiving) your precious letter. When the esteemed (endoxotēs) brother Mata needed a small (amount) of wool, black or color, I met our brother the lord Saleh. He went to the south and I annulled his affair. I requested him and I sent him to you (pl.), so that you (pl.) come to agreement with him and so that he take them (i.e. the wool) and bring them to me as well as all that you (pl.) will find a garment of good quality, take it (and) send them [sic] to me through him ...

The sender is at least Papas' equal. The individual named Mata bears the title of endoxotēs, which seems reserved in this archive to the topotērētēs or to the chartularius of the pagarch. He could be an Arab and apparently someone of importance, since the sender sends a man on purpose, namely the lord Saleh, after canceling his previous task, in order to procure Mata a little wool. On this occasion, Papas and his correspondent probably had to collaborate to satisfy the wish coming from above as quickly as possible.

\subsection{Complaints and requests from "below"}

These letters are often characterized by more deferential politeness formulas, and by long complaints, partly rhetorical, but also revealing of the distress caused by the weight of the requisitions. A nice illustration is offered by a long letter addressed to Papas by an individual who had to execute a requisition at the local level, and struggled to do so: $:^{23}$

... As for the workmen about whom you have written and threatened me, here is ... May the deacon complete (the requisition?), either sailors, workers or pistikoi ... But do not let me bear the accusation of eating bread that is yours, to give a carat that is yours, (for I will then have no other choice) otherwise (than) to become servant/slave to your city, serving on your boats (as) less than a pistikos, or to go to Babylon in the condition of servant/slave ... By pushing these things to an end, I am forming the thought of becoming a caulker (?) ... for your city ... Above all I weep and beg the antidux ... Shenoute stood up and said: "If you leave in secret, I will send for your wife and take her to Babylon." And ... she was taken away and hidden (?) ... In addition to these things, I embrace the footstool of your feet until I see you. With God. And above all I greet ... and your blessed house. Hail in the power of the Holy Trinity. The Lord be with you.

22 P.IFAO Edfou Jarre inv. 11, see Ochała in Boud'hors/Delattre (2017) 98-102.

23 P.IFAO Edfou Jarre inv. 25, edition in preparation. 
Particularly interesting here is the use of the term antidux, for which we have another attestation in the Coptic texts of the archive, and an occurrence outside the archive in P.Gascou 25, a document related to the monastery of Saint Jeremiah in Saqqara. In his recent article "Duchi ed emiri", Federico Morelli pointed out that the dux is almost entirely absent from P.Apoll. (with the exception of P.Apoll. 9). The topotereetēes seems to be the person with whom the amir liaises, much more than the $d u x$. Is it possible to hypothesize a temporary vacancy or interim period, during which the topotēētès was acting and playing the role of the $d u x ?^{24}$ On the other hand, since the word topoterēetēs has not apparently been attested in Coptic documents before this period, could the Coptic antidux be equivalent to topotêrētēs? All these questions cannot yet be answered. It seems, for instance, that the $d u x$ appears in at least three Coptic documents. Things are probably more complicated.

\subsection{Papas' network and the use of languages}

The network of correspondents, of which Papas is the center, can be essentially represented by the diagram below: ${ }^{25}$

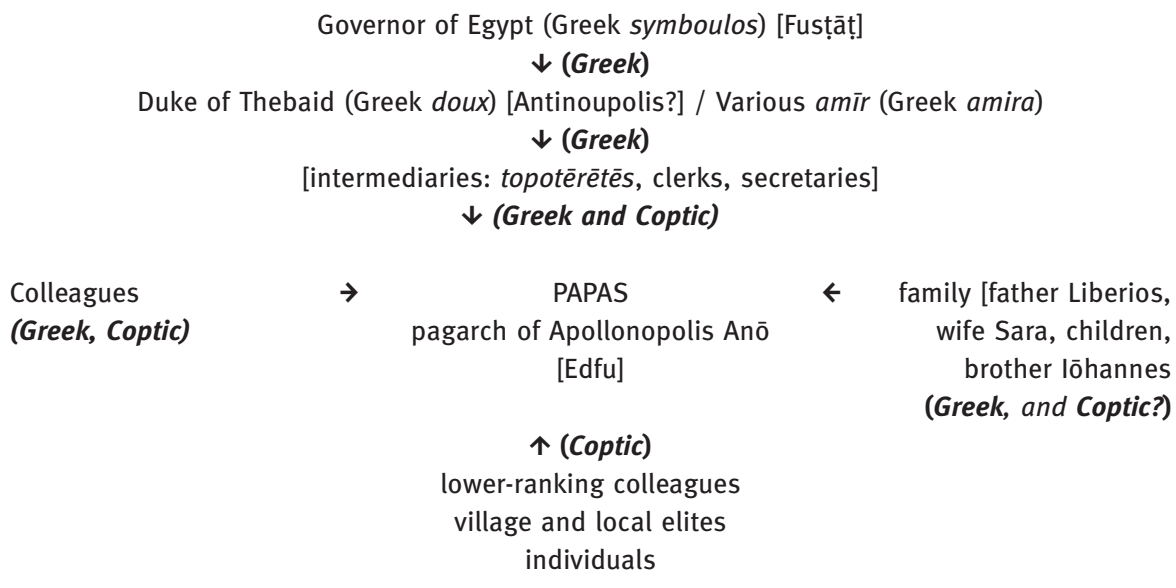

Colleagues

(Greek, Coptic)

$\rightarrow$

PAPAS
pagarch of Apollonopolis An
[Edfu]
$\uparrow$ (Coptic)
lower-ranking colleagues
village and local elites
individuals

$\leftarrow \quad$ family [father Liberios, wife Sara, children, brother lōhannes (Greek, and Coptic?)

As I hope to have shown, the Coptic texts obviously allow us to situate the figure of Papas as a member of a bilingual Christian elite, but not in a simple division between public and private. The Greek and Coptic texts in the official sphere complement

24 Morelli (2016) 281.

25 This diagram is inspired by the table provided in Richter (2010) 215. The main difference is that there are no Arabic letters addressed to Papas, but this is unsurprising, since such letters in the Qurra dossier are probably a consequence of the reforms of the late seventh century, which aimed, inter alia, at increasing the Arabization of the administration. 
each other. The modalities of this complementarity remain to be defined, and this will be one of the ongoing tasks of the team now working on this archive.

\section{Bibliography}

Boud'hors/Delattre (2017): Anne Boud'hors and Alain Delattre, “Un nouveau départ pour les archives de Papas: Papyrus coptes et grecs de la jarre d'Edfou", in: BIFAO 117, 87-124.

Boud'hors/Delattre (2018): Anne Boud'hors and Alain Delattre, "Papyrus coptes et grecs de la jarre d'Edfou (suite)", in: BIFAO 118, 1- 45.

Crum (1925): Walter E. Crum, "Koptische Zünfte und das Pfeffermonopol”, in: Zeitschrift für Ägyptische Sprache und Altertumskunde 60, 103-111.

Foss (2009): Clive Foss, “Egypt under Mu'āwiya. Part I: Flavius Papas and Upper Egypt”, in: Bulletin of the School of Oriental and African Studies 72.1, 1-24.

Garel (2017): Esther Garel, “Le titre ПlגKOY dans les documents coptes fayoumiques”, in: Maria Nowak, Adam tajtar, and Jakub Urbanik (eds.), Tell Me Who You Are. Labelling Status in the Graeco-Roman World, Truskaw, 57-72.

Gascou/Worp (1982): Jean Gascou and Klaas A. Worp, “Problèmes de documentation apollinopolite", in: Zeitschrift für Papyrologie und Epigraphik 49, 83-95.

MacCoull (1988): Leslie S. MacCoull, “The Coptic Papyri from Apollonos Ano”, in: Basil G. Mandilaras (ed.), Proceedings of the 18th International Congress of Papyrology. Athens, 25-31 May 1986, Athens, vol. II, 141-160.

Marchand (2013): Sylvie Marchand, “La 'jarre aux papyrus' d’Edfou et autres jarres de stockage d'époque arabe découvertes à Tebtynis, Fayoum (deuxième moitié du $\mathrm{VII}^{\mathrm{e}}-\mathrm{X}^{\mathrm{e}}$ siècle apr. J.-C.)", in: Bettina Bader and Mary F. Ownby (eds.), Functional Aspects of Egyptian Ceramics in Their Archaeological Context. Proceedings of a Conference Held at the McDonald Institute for Archaeological Research, Cambridge, July 24th-July 25th, 2009 (Orientalia Lovaniensia Analecta 217), Leuven, Paris, and Walpole, MA, 327-349.

Morelli (2016): Federico Morelli, "Duchi ed emiri. II gioco delle scatole cinesi in PSI XII 1266/P. Apoll. 9", in: Angelo Casanova et al. (eds.), E si d'amici pieno. Omaggio di studiosi italiani a Guido Bastianini per il suo settantesimo compleanno, I: Papirologia-Egittologia, Florence, 267-282.

Papaconstantinou (2012): Arietta Papaconstantinou, “Donation and negotiation. Formal gifts to religious institutions of Late Antiquity”, in: Jean-Michel Spieser and Élisabeth Yota (eds.), Donations et donateurs dans la société et l'art byzantins (Réalités byzantines), Paris, 75-95. Rémondon (1953): Roger Rémondon, Papyrus grecs d'Apollonos Anô (Documents de Fouilles 19), Cairo.

Rémondon (1972): Roger Rémondon, “L’Église dans la société égyptienne à l'époque byzantine”, in Chronique d'Égypte 47.93-94, 254-277.

Richter (2010): Tonio Sebastian Richter, “Language choice in the Qurra dossier”, in: Arietta Papaconstantinou (ed.), The Multilingual Experience in Egypt, from the Ptolemies to the 'Abbāsids, Ashgate, 189-220.

Tost (2012): Sven Tost, "Die Unterscheidung zwischen öffentlicher und privatgeschäftlicher Sphäre am Beispiel des Amts der riparii”, in: Paul Schubert (ed.), Actes du $26^{e}$ Congrès international de papyrologie. Genève, 16-21 août 2010, Genève, 773-780. 
